\title{
NEUROD1 Gene
}

National Cancer Institute

\section{Source}

National Cancer Institute. NEUROD1 Gene. NCI Thesaurus. Code C98200.

This gene plays a role in both transcriptional activation and DNA binding. 